\title{
References:
}

1. Derzhavnyy reyestr sortiv roslyn, prydatnykh dlya poshyrennya v Ukrayini na 2020 rik [State register of plant varieties suitable for distribution in Ukraine for 2020]. Ukrainian institute for expertise of plant varieties (electronic site). Retrieved from: https://sops.gov.ua/reestr-sortiv-roslin (accessed 17 March 2020).

2. Havrylyuk, V. M. (2010). Vrozhayi yevropeys'ki - sorty ukrayins'ki [European crops - Ukrainian varieties]. Seeds, no. 4, pp. 16-19. (in Ukrainian)

3. Zakharchuk, O. V. (2009). Sort yak innovatsiyna osnova dlya rozvytku roslynnytstva [Sort as an innovative basis for the development of plant growing]. Agroinkom, no. 5-8, pp. 21-22. (in Ukrainian)

4. Onychko, V. I., Berdin, S. I., \& Tkachenko, O. M. (2015). Vplyv udobrennya ta norm vysivu nasinnya na vrozhaynist' riznykh za morfotypom sortiv hrechky [The influence of fertilizer and seed rates on the yield of different varieties of buckwheat varieties]. Bulletin of Sumy NAU, vol. 3(29), pp. 25-29. (in Ukrainian)

5. Volkodav, V. V. (2008). Inozemni fakhivtsi stverdzhuyut', shcho vysokoyakisni resursy Ukrayiny - naykrashchi v Skhidniy ta Tsentral'niy Yevropi [Foreign specialists assert that of high quality resources of Ukraine - the best in Eastern and Central Europe]. Grain and bread, no. 2, pp. 50-51. (in Ukrainian)

\section{THE EFFECT OF HUMIC FERTILIZERS ON THE CORN GRAIN YIELD}

\section{Yevhen Havilei $^{1}$ \\ Viktor Onychko ${ }^{2}$}

DOI: https://doi.org/10.30525/978-9934-588-39-6-30

Due to its properties, corn is used in human feed, animal feed, as well as industrial raw material for technical purposes and for the production of biogas and electricity. Corn grain is rich in energy, protein and fats but not very rich in minerals [1, p. 28-29].

In recent years, production has shown that not only the high level of yield of the hybrid is crucial in its choice for cultivation, but also the ability to maintain its high lower threshold in unfavorable growing conditions, which is determined by the adaptive potential of plants.

It should be emphasized that when receiving high yield of corn grain, while preserving soil fertility and its microbiological composition, it is not always possible to solve this issue with one element of technology -

\footnotetext{
${ }^{1}$ Sumy National Agrarian University, Ukraine

${ }^{2}$ Sumy National Agrarian University, Ukraine
} 
it requires a complex approach with the use of biological preparations, antistressants, liquid fertilizers and humates in high-productive hybrids [4].

The effect of humic fertilizers on plants has complex multistage character and covers the entire growing season. First, with humic fertilizers, plants get a certain amount of nutrients - nitrogen, phosphorus, potassium, sulfur, calcium, trace elements, as well as vitamins, amino acids and growth substances. Secondly, by entering the plants, humic substances activate the enzymatic activity of all the cells of the plant. As a result there is the growth of cell energy, changes in the physical and chemical properties of the protoplasm, and intensification of cell metabolism.

Methodology of conducting researches. The researches were conducted on the basis of the research point of JSC «Prydniprovskyi Krai» of the Kernel Agroholding.

The laying of experiments was carried out according to the scheme of onefactor experiment. The acreage of the plots was 5 hectares, the accounting area was 3.68 hectares, the repetition - four times, which meets the requirements of conducting experiments with cereals. The alternation of variants in the recurrence was consistent.

The background to the experiment was the following elements of the technology of cultivation: mulching plant residues; introduction of CAS 32 at the rate of $30 \mathrm{~kg} /$ ha in combination with the stubble destroyer Ekostern $1.5 \mathrm{l} / \mathrm{ha}$; utilization of plant residues with disc-shaped tools with simultaneous application of N8P20K30 at the rate of $120 \mathrm{~kg} /$ ha; pre-sowing cultivation; sowing with liquid complex fertilizer Quantum Diafan N5P20K5 $20 \mathrm{~kg} / \mathrm{ha}$; application of soil herbicide Kratos, $2.5 \mathrm{l} /$ ha. The DKS 4590 maize hybrid was used as the test object.

The results of the researches. As a result of the conducted researches it was found that the introduction of humates during sowing in a row when growing DKS 4590 hybrid corn gives an increase in yield compared with the control from $0.05 \mathrm{t} /$ ha to $0.43 \mathrm{t} /$ ha (Figure 1 ).

The use of Humifild VR 18 fertilizer with a rate of $0.4 \mathrm{l} /$ ha did not contribute to a significant level of yield increase. The use of Humifild Forte Briks fertilizer with a rate of $0.4 \mathrm{l} /$ ha allowed for a yield gain of $0.04 \mathrm{t} /$ ha compared to the control variant. The introduction of humic fertilizer humates LF 20 allowed to increase yields of 0.31 and $0.43 \mathrm{t} / \mathrm{ha}$, depending on the rate of its application. Higher yields were obtained with the application of $0.5 \mathrm{l} /$ ha of fertilizer.

Thus, in modern conditions of management it is rational to use fertilizers based on humic acids in combination with the introduction of liquid complex fertilizers, which affects the overall course of metabolism in plants and the processes of their growth. More effective is the use of LF humate (0.5 l / ha) and Humifild Fort Briks (0.4 l / ha). 


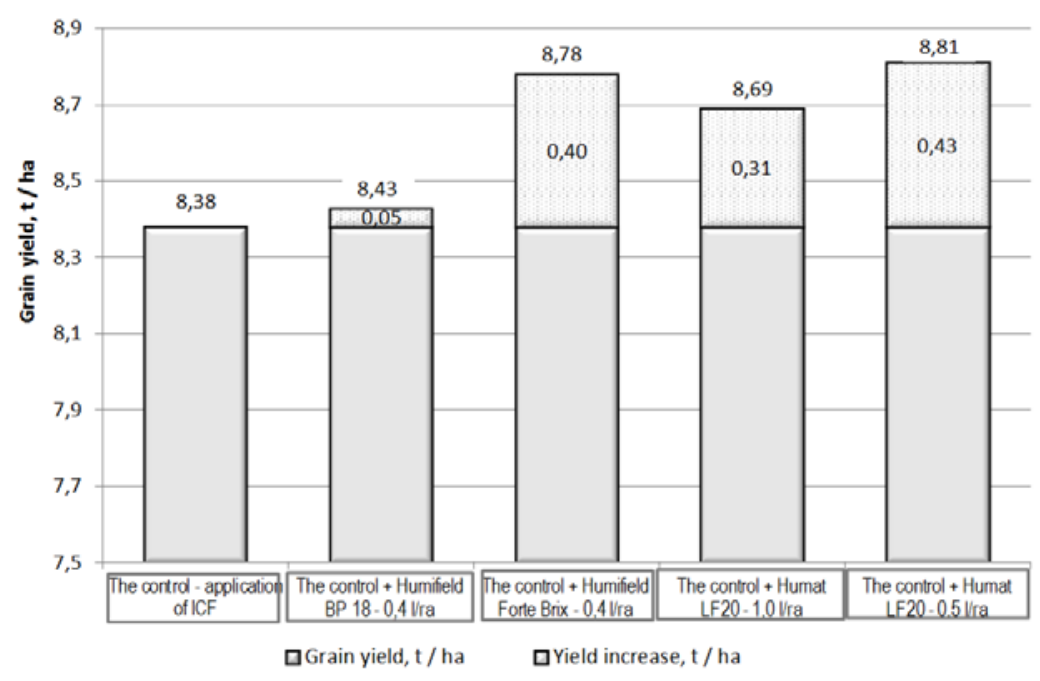

Figure 1. The effect of humic fertilizers on the corn grain yield

\section{References:}

1. Diter Shpaar (2012). Kukuruza : vyrashchivaniye, uborka, khraneniye $i$ ispol'zovaniye [Corn: growing, harvesting, storage and use]. Izdatel'skiy dom «Zerno». (in Ukrainian)

2. Dospekhov B. A. (1985). Metodika polevogo opyta (s osnovami statisticheskoy obrabotki rezul'tatov issledovaniy) [Methods of field experience (with the basics of statistical processing of research results)]. Moskva: Agropromizdat. (in Russian)

3. Instytut zemlerobstva UAAN (2001). Metodychni vkazivky shhodo provedennja poljovykh doslidzhenj i vyvchennja tekhnologhiji vyroshhuvannja zernovykh kuljtur [Methodical for the design of field operations and cultivation of grain crops]. Cabany. (in Ukrainian)

4. Tarasenko Oleksiy (2019). Udobrennya kukurudzy vid A do YA [Fertilizer of corn from A to Z]. Ahronom (electronic journal), Retrieved from: https://www.agronom.com.ua/ udobrennya-kukurudzy-vid-a-do-ya (accessed 19 March 2020). 